\title{
The Experimental and Simulation Study of Selective Catalytic Reduction System in a Single Cylinder Diesel Engine Using $\mathbf{N H}_{3}$ as a Reducing Agent
}

\author{
Manoj Kumar Athrashalil Phaily, Sreekumar Jayachandra Sreekala, \\ and Padmanabha Mohanan
}

Department of Mechanical Engineering, NITK Surathkal, Karnataka, Mangalore 575025, India

Correspondence should be addressed to Manoj Kumar Athrashalil Phaily; manu666240@gmail.com

Received 21 November 2013; Revised 13 March 2014; Accepted 14 March 2014; Published 15 April 2014

Academic Editor: Alírio Rodrigues

Copyright (C) 2014 Manoj Kumar Athrashalil Phaily et al. This is an open access article distributed under the Creative Commons Attribution License, which permits unrestricted use, distribution, and reproduction in any medium, provided the original work is properly cited.

\begin{abstract}
Selective catalytic reduction (SCR) technology has been widely used in automotive applications in order to meet the stringent limits on emission standards. The maximum NOx conversion efficiency of an SCR depends on temperature and mass flow rate of an exhaust gas. In order to assess the suitability of Cordierite/Pt catalyst for low temperature application, an experimental work is carried out using single cylinder diesel engine for different load conditions by varying ammonia induction rate from $0.2 \mathrm{~kg} / \mathrm{hr}$ to $0.8 \mathrm{~kg} / \mathrm{hr}$. The simulation is carried out using AVL FIRE for the validation of experimental results. From the study, it has been found that for $0.6 \mathrm{~kg} / \mathrm{hr}$ ammonia induction rate the maximum conversion is achieved, whereas, for $0.8 \mathrm{~kg} / \mathrm{hr}$, conversion is reduced due to desorption of ammonia. Also it has been found that, at $75 \%$ of load, for all mass flow rates of ammonia the conversion was drastically reduced due to higher exhaust gas temperature and higher emission of unburnt hydrocarbons. More than $55 \%$ of NO $x$ conversion was achieved using Cordierite/Pt catalyst at a temperature of $320^{\circ} \mathrm{C}$.
\end{abstract}

\section{Introduction}

In $\mathrm{NH}_{3} \mathrm{SCR}$ system, $\mathrm{NH}_{3}$ is inducted to the exhaust gas coming out from the engine exhaust, which will undergo various reactions to convert $\mathrm{NO} x$ into free nitrogen $\left(\mathrm{N}_{2}\right)$.

The most important reactions are

$$
\begin{gathered}
4 \mathrm{NH}_{3}+4 \mathrm{NO}+\mathrm{O}_{2} \longrightarrow 4 \mathrm{~N}_{2}+6 \mathrm{H}_{2} \mathrm{O} \\
4 \mathrm{NH}_{3}+2 \mathrm{NO}+2 \mathrm{NO}_{2} \longrightarrow 4 \mathrm{~N}_{2}+6 \mathrm{H}_{2} \mathrm{O}
\end{gathered}
$$

Two most commonly used SCR reductants are anhydrous (dry) ammonia and aqueous ammonia or urea. Pure anhydrous ammonia is extremely toxic and difficult to store safely but does not require further conversion to operate within an SCR. It is typically favoured by large industrial SCR operators. Aqueous ammonia must be hydrolyzed in order to use, but it is substantially safer to store and transport than anhydrous ammonia. Urea is the safest to store but requires conversion to ammonia through thermal decomposition in order to be used as an effective reductant. The temperatureprogrammed activity of a series of oxide-supported $\left(\mathrm{TiO}_{2}\right.$, $\mathrm{Al}_{2} \mathrm{O}_{3}$, and $\mathrm{SiO}_{2}$ ) Cu catalysts formed from two different $\mathrm{Cu}$ precursors $\left(\mathrm{Cu}\left(\mathrm{NO}_{3}\right)_{2}\right.$ and $\left.\mathrm{CuSO}_{4}\right)$ for the selective catalytic reduction of NOx using solutions of urea as a reductant [1]. These activities are compared to those found using $\mathrm{NH}_{3}$ as a reducing agent over the same catalysts in the presence of $\mathrm{H}_{2} \mathrm{O}$ and it is found that catalysts that are active for the selective reduction of $\mathrm{NO} x$ with $\mathrm{NH}_{3}$ are inactive for its reduction using solutions of urea. However, catalyst plays a major role in the conversion of $\mathrm{NO} x . \mathrm{V}_{2} \mathrm{O}_{5} / \mathrm{Al}_{2} \mathrm{O}_{3}$ catalysts can be used for operating temperature higher than $250^{\circ} \mathrm{C}$ but restricted to sulphur free application due to deactivation of the catalyst from alumina reaction with $\mathrm{SO}_{3}$ forming $\mathrm{Al}_{2}\left(\mathrm{SO}_{4}\right)_{3}$. The nonsulphating $\mathrm{TiO}_{2}$ carrier was recommended for the $\mathrm{V}_{2} \mathrm{O}_{5}$. Studies that have been carried out with $\mathrm{V}_{2} \mathrm{O}_{5}$ catalyst 


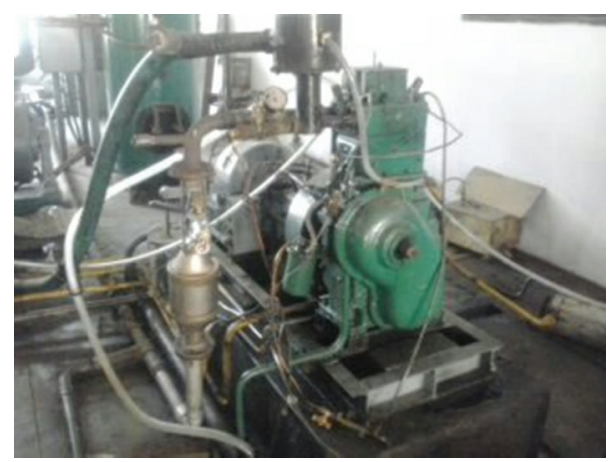

FIgURE 1: Experimental test rig.

supported on $\mathrm{TiO}_{2}$ and $\mathrm{WO}_{3}$ used for Heavy Duty diesel Engines in Europe with numerous highway studies [2].

The studies highlighted that problems with vanadium catalyst are quickly deactivated at high temperatures above $500^{\circ} \mathrm{C}$ and concluded that recommended temperature window for vanadium is from 300 to $450^{\circ} \mathrm{C}$ [3]. Zeolite catalysts are developed to cover a wider range of temperature windows over platinum- and vanadium-based catalysts. Zeolite catalysts are developed to extend the operating temperature above $350^{\circ} \mathrm{C}$ over platinum and vanadium based catalysts. However, two types of zeolite catalysts were developed to cover high and low temperature windows. The high temperature zeolite covers temperature windows from 350 to $600^{\circ} \mathrm{C}$. Automotive catalytic converters constantly heat up and cool down as the engine starts and stops. This requires some special material with the greatest possible resistance to change temperature and a low heat expansion coefficient. There are studies conducted on the effect of $\mathrm{HC}$ emission on the retarded activity of SCR catalysts [4]. They considered CuZSM5, FeZSM5, and $\mathrm{V}_{2} \mathrm{O}_{5} / \mathrm{TiO}_{2}$ catalysts and compared the effect of $\mathrm{HC}$ emission on the DeNO $x$ efficiency of SCR catalyst. They concluded that the primary cause for the inhibition is the competitive adsorption of $\mathrm{NH}_{3}$ and $\mathrm{C}_{3} \mathrm{H}_{6}$ onto the catalyst surface and the useless consumption of $\mathrm{NH}_{3}$ by the side reaction, including the $\mathrm{NH}_{3}$ oxidation and ammoxidation reactions during the course of $\mathrm{NH}_{3} / \mathrm{SCR}$ reaction with $\mathrm{C}_{3} \mathrm{H}_{6}$. Another study was conducted on the effect of unburnt hydrocarbons in the activity of automobile catalysts [5]. The study reveals that the NOx conversion efficiency of SCR catalyst will reduce, when there is an $\mathrm{HC}$ in exhaust gas. When HCs are added to the flow, some C-species deposit forms on the surface. This result is consistent with a pore blocking effect which will slightly affect the NO $x$ removal at the highest reaction temperature. They also found that the most important effect of HC presence on the SCR activity is due to the competitive adsorption between hydrocarbons and ammonia which limits the NO $x$ conversion efficiency of SCR.

In the current work, Cordierite/Pt ceramic honeycomb structured catalyst has been used to assess the suitability of this material for the medium and light duty diesel vehicles as it gives resistance to temperature changes and a low heat expansion coefficient.

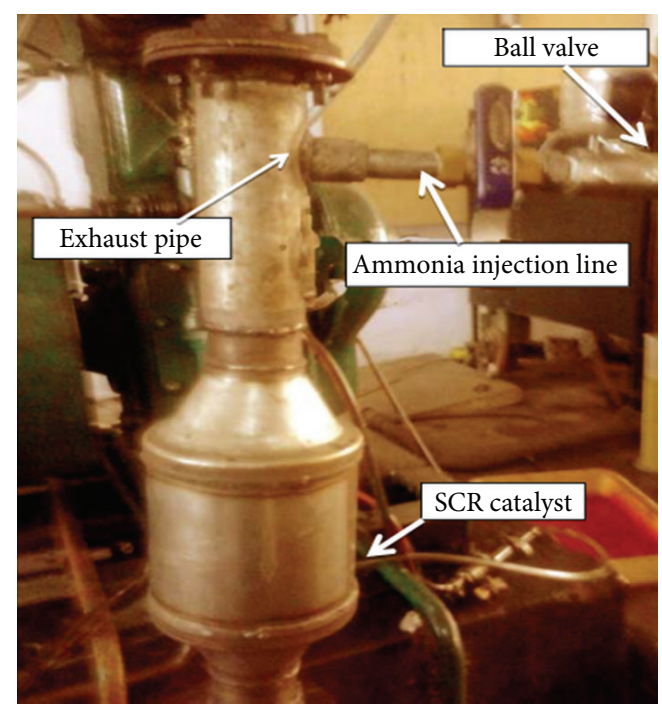

FIGURE 2: SCR setup.

TABLE 1: SCR catalyst properties.

\begin{tabular}{lc}
\hline Catalyst material & Cordierite $/ \mathrm{Pt}$ \\
Catalyst type & Circular honeycomb structure \\
Size of the catalyst & $118.4 \mathrm{~mm} \times 127 \mathrm{~mm}(D \times L)$ \\
Specific heat & $1.46 \mathrm{~kJ} / \mathrm{kgK}$ \\
Cell density & $4001 / \mathrm{in}^{2}$ \\
Volume of catalyst & $1.2 \mathrm{~L}$ \\
Wall thickness & $0.114 \mathrm{~mm}$ \\
Density & $0.0215 \mathrm{~kg} / \mathrm{m}^{3}$ \\
Thermal conductivity & $3 \mathrm{~W} / \mathrm{mK}$ \\
\hline
\end{tabular}

\section{Experimental Work}

Whole set of experiments were conducted at the designed injection timing of $27 \mathrm{deg}$ bTDC, speed of $1500 \mathrm{rpm}$, and 17.5 compression ratio on test rig as shown in Figure 1.

Airflow measurement was done by the conventional method U-tube manometer as well as by air intake DP unit in the control panel. Engine speed measurement was sensed and inducted by inductive pickup sensor in conjunction with digital RPM indicator, which is a part of eddy current dynamometer controlling unit. The dynamometer shaft rotates close to inductive pickup sensor as an arrangement to send voltage pulse whose frequency is converted into RPM and displayed by digital indicator in the control panel. To measure the load on the engine, an eddy current dynamometer is attached to the crankshaft of the engine. An AVL-made exhaust gas analyzer was used to measure the exhaust gas emissions. With the analyzer, NOx (ppm), CO (\%vol.), UBHC (ppm), and $\mathrm{CO}_{2}$ (\%vol.) emissions were measured. A rotameter specially calibrated for ammonia was used to measure the flow rate of ammonia. The experiments were conducted at no load, 25\% of full load, $50 \%$ of full load, and $75 \%$ of full load condition with diesel fuel.

The experiment is conducted on two conditions: firstly, without using SCR at the exhaust pipe and, secondly, fitting 


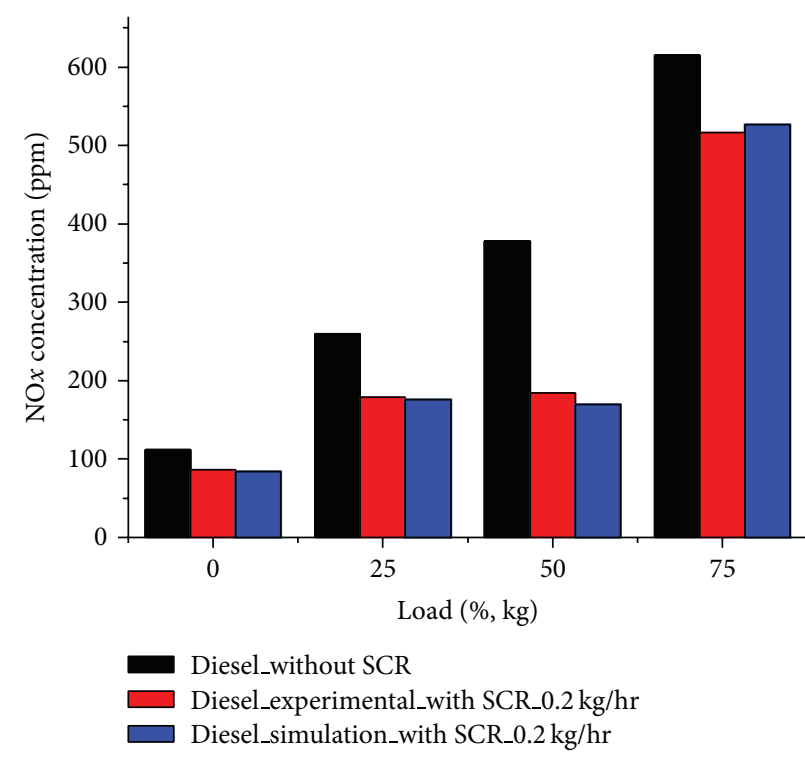

(a)

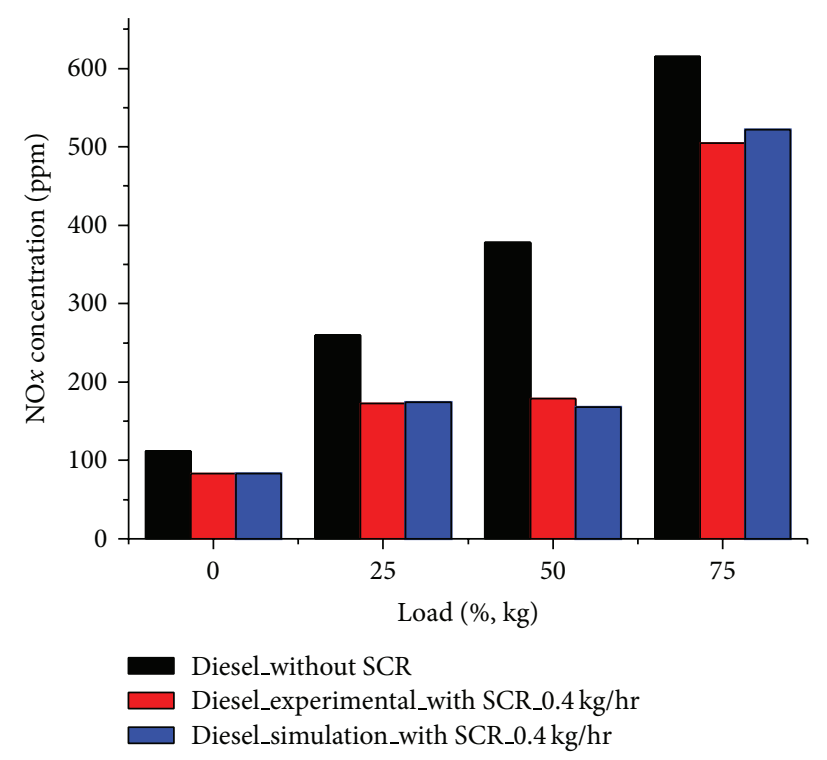

(c)

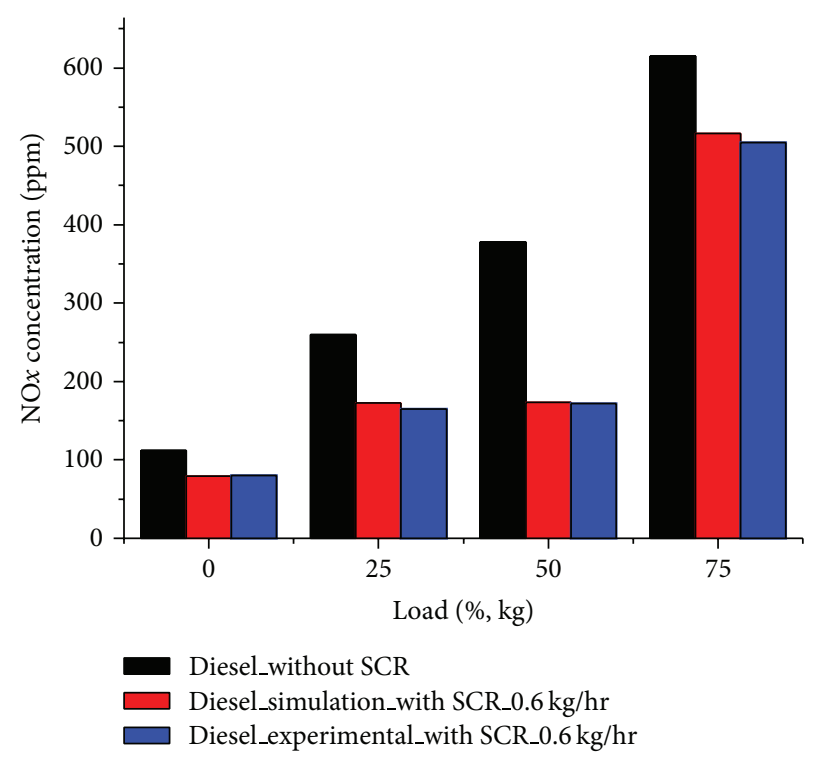

(b)

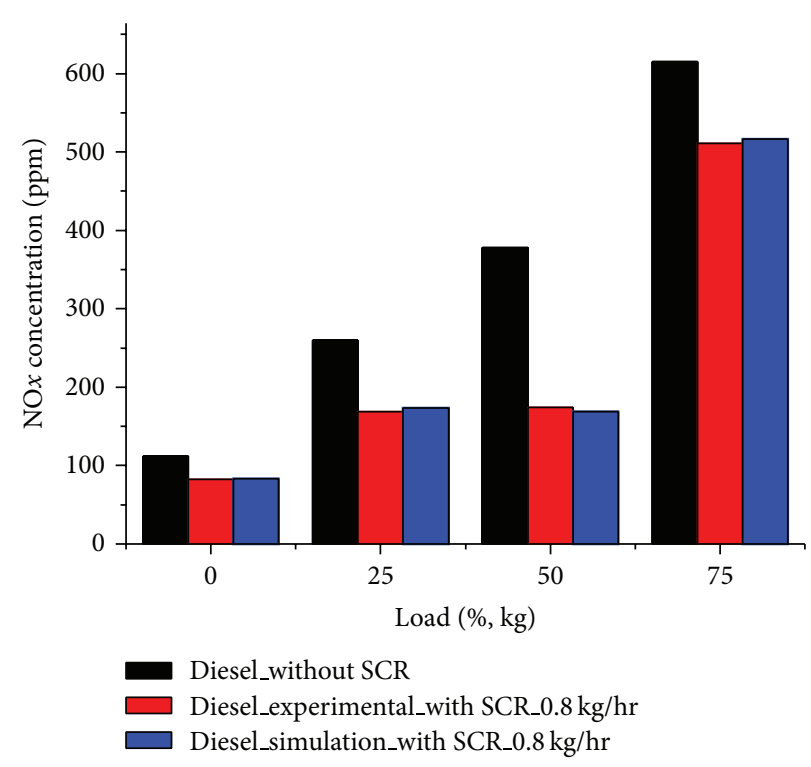

(d)

Figure 3: Concentration of NOx versus percentage of load.

SCR catalyst at the exhaust pipe. Both the readings will be tabulated and can find the DeNO $x$ efficiency of SCR.

\section{SCR Setup}

In this experimental setup, a circular shaped, honeycomb type of SCR catalyst (Cordierite/Pt, $1.2 \mathrm{~L}$ ) is fitted to the exhaust pipe with flange supports as shown in Figure 2. Sealing gaskets were placed in between two flange connections. The gasket used was a high temperature resistance type to prevent gas leakage from the exhaust system. Some minor adjustment was necessary in the final SCR exhaust assembly because of the restricted space within the cell. A half inch barrel nipple of length of 3 inches is coupled to the exhaust pipe through which ammonia gas is passed.

A hose pipe from the ammonia cylinder is connected to ammonia rotameter, where the ammonia flow rate can be controlled by turning the regulating knob.

\section{Simulation Work}

The simulation has been carried out using CFD code AVL FIRE. The governing equations and reactions used in AVL FIRE are listed in [5]. The properties of the material are shown in Table 1. 


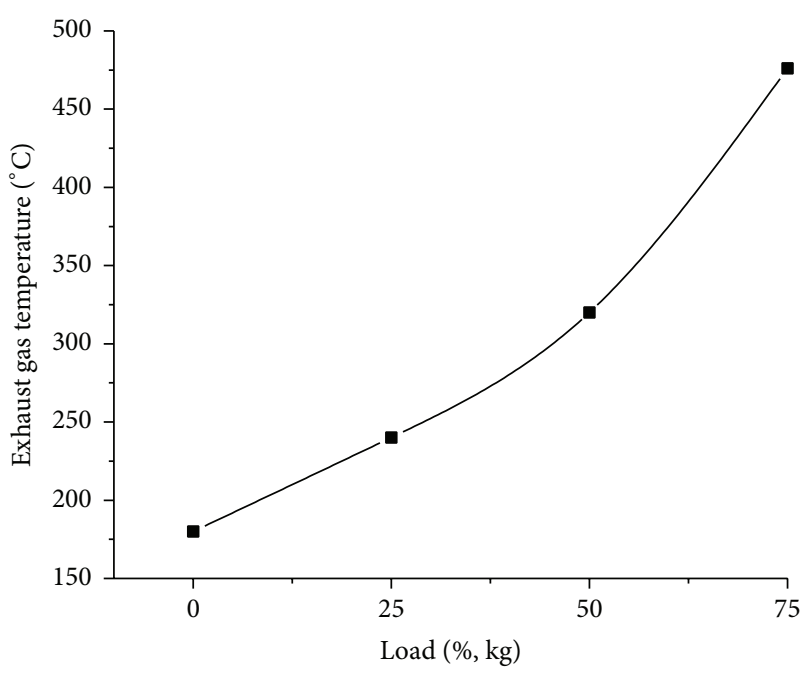

FIGURE 4: Variation of exhaust gas temperature versus percentage of load.

The mass flow rate of exhaust gas is calculated for different load conditions. It was found that as the load increases, the mass flow rate of exhaust gas decreases. This is due to change in density of gas. When load increases, exhaust gas temperature also increases, which results in lower density of a gas. The boundary conditions considered in the simulation are given in Table 2. The normalized residual values for the convergence criteria were taken as 1e- 4 for continuity, momentum, and energy equations. It took 60 iterations to reach the convergence. The maximum iteration was limited to 60 , since the solution arrived at was close to the exact solution (experimental values) within these convergence criteria.

The mass fractions of different species including $\mathrm{NO} x$, $\mathrm{CO}, \mathrm{CO}_{2}, \mathrm{H}_{2}$, and $\mathrm{HC}$ are considered from experimental values, measured by AVL Five gas analyzer. The outlet pressure was assumed to be 1 bar. The mass flow rate and temperature of exhaust gas are also given as input which is measured by experimental work. The SCR catalyst was modeled using the abovementioned dimensions and meshed in AVL Workflow manager. The simulation is carried out for different load conditions by varying ammonia flow rate from $0.2 \mathrm{~kg} / \mathrm{hr}$ to $0.8 \mathrm{~kg} / \mathrm{hr}$.

\section{Results and Discussion}

The experiment was carried out for diesel fuel by varying load conditions. It reveals that as the load increases, the exhaust gas temperature increases. The flow rate of ammonia is also varied from $0.2 \mathrm{~kg} / \mathrm{hr}$ to $0.8 \mathrm{~kg} / \mathrm{hr}$. The three major factors which have got significant effect in the conversion of $\mathrm{NO} x$ are exhaust gas temperature, exhaust gas mass flow rate, and ammonia flow rate.

The SCR catalyst used in the experiment can withstand temperature range up to $500^{\circ} \mathrm{C}$. Therefore, the load condition applied was limited to $75 \%$ of full load where exhaust gas temperature was found to be $486^{\circ} \mathrm{C}$. At $100 \%$ of load, the temperature will go beyond $520^{\circ} \mathrm{C}$, which will damage the
SCR catalyst, which in turn affects the exhaust gas analyser. The experiment has been carried out for two conditions. In the first case, SCR catalyst was not fitted at the downstream exhaust pipe. Engine was run for different load conditions and the concentration of NO $x$ was measured directly by AVLmade Five gas analyser. In the second case, the SCR catalyst has been fitted at the exhaust pipe. The ammonia gas was inducted to the exhaust pipe just before SCR setup. The flow rate has been varied from $0.2 \mathrm{~kg} / \mathrm{hr}$ to $0.8 \mathrm{~kg} / \mathrm{hr}$. Again the engine can run in varying load conditions. The concentration of $\mathrm{NO} x$ can again be measured by exhaust gas analyzer. Figure 3 explains the concentration of $\mathrm{NO} x$ measured for both the conditions explained above.

From Figure 3, it is clear that as the load increases, the concentration of NOx also increases because of higher combustion temperature. The higher combustion temperature results in higher exhaust gas temperature.

Figure 4 explains the variation of exhaust gas temperature with respect to varying load conditions. It shows that as the percentage load increases, the exhaust gas temperature also increases. At no load condition $180^{\circ} \mathrm{C}$ temperature was observed, whereas at $25 \%$ of full load, at $50 \%$ of full load. and at $75 \%$ of full load $260^{\circ} \mathrm{C}, 378^{\circ} \mathrm{C}$, and $486^{\circ} \mathrm{C}$ temperatures have been observed. From the graph it can be clearly observed that, at $50 \%$ of full load for all the ammonia flow rates, maximum conversion has been observed, where NOx concentration was reduced from $378 \mathrm{ppm}$ to $169 \mathrm{ppm}$. This is because the catalyst exhibited the maximum selectivity at the temperature of $378^{\circ} \mathrm{C}$. The minimum conversion is observed at $75 \%$ of full load, where NOx concentration was reduced from $615 \mathrm{ppm}$ to $526 \mathrm{ppm}$. The NO $x$ conversion with respect to varying load condition is explained in Figure 5.

It was found that, up to $50 \%$ load, NO $x$ conversion keeps on increasing, whereas, at $75 \%$ load, DeNO $x$ efficiency is drastically reduced. Similar pattern of graph is observed for all the ammonia mass flow rate conditions. It was found that the experimental values are in close agreement with simulation results. The increase in NOx conversion is due to increase in exhaust gas temperature. At 50\% load, maximum conversion is obtained since the exhaust gas temperature is $320^{\circ} \mathrm{C}$ where the catalyst exhibits maximum selectivity, due to which fast SCR reaction takes place, which in turn converts $\mathrm{NO} x$ into free nitrogen $\left(\mathrm{N}_{2}\right)$. It was found that, for $0.2 \mathrm{~kg} / \mathrm{hr}$ of ammonia induction, at no load condition, up to $25 \%$ of NO $x$ conversion is achieved. Similarly for $0.4 \mathrm{~kg} / \mathrm{hr}$, $0.6 \mathrm{~kg} / \mathrm{hr}$, and $0.8 \mathrm{~kg} / \mathrm{hr}$ of ammonia induction rate, $26 \%$, $29 \%$, and $27 \%$ of NOx conversion are achieved as shown in Figure 5. Similarly at $25 \%$ load, for $0.2 \mathrm{~kg} / \mathrm{hr}, 0.4 \mathrm{~kg} / \mathrm{hr}$, $0.6 \mathrm{~kg} / \mathrm{hr}$, and $0.8 \mathrm{~kg} / \mathrm{hr}$ ammonia induction rate, $31 \%, 33 \%$, $36 \%$, and $34 \%$ of NOx conversion are achieved. A slight increment in NOx conversion is achieved at $25 \%$ load, because of increased exhaust gas temperature and lower mass flow rate of exhaust gas. At 50\% load, maximum conversion is obtained for all the mass flow rates. It was found that, at $0.2 \mathrm{~kg} / \mathrm{hr}$ ammonia induction, $55 \%$ of $\mathrm{NO} x$ conversion is obtained. Similarly for $0.4 \mathrm{~kg} / \mathrm{hr}, 0.6 \mathrm{~kg} / \mathrm{hr}$, and $0.8 \mathrm{~kg} / \mathrm{hr}$ ammonia induction, $55 \%, 55 \%$, and $54 \%$ of $\mathrm{NO} x$ conversion 
TABLE 2: Boundary conditions used in the simulation work.

\begin{tabular}{|c|c|c|c|c|}
\hline \multicolumn{5}{|c|}{ Solver control discretization } \\
\hline $\begin{array}{l}\text { Calculation of boundary } \\
\text { conditions: extrapolate }\end{array}$ & $\begin{array}{c}\text { Calculation of derivatives: } \\
\text { least square fit }\end{array}$ & Iteration method: simple & Decoupled domains: no & $\begin{array}{c}\text { Realizability constraints: } \\
\text { no }\end{array}$ \\
\hline \multicolumn{5}{|c|}{ Equation control } \\
\hline $\begin{array}{l}\text { Momentum and continuity: } \\
\text { yes }\end{array}$ & Turbulence: K-epsilon & Energy: yes & Viscous heating: yes & Pressure work: yes \\
\hline \multicolumn{5}{|c|}{ Differencing scheme } \\
\hline $\begin{array}{l}\text { Momentum: central } \\
\text { differencing }\end{array}$ & $\begin{array}{l}\text { Continuity: central } \\
\text { differencing }\end{array}$ & Turbulence: upwind & Energy: upwind & Scalar: upwind \\
\hline \multicolumn{5}{|c|}{ Convergence criteria per time step } \\
\hline \multicolumn{2}{|c|}{ Maximum number of iterations: 60} & \multicolumn{3}{|c|}{ Minimum number of iterations: 10} \\
\hline
\end{tabular}

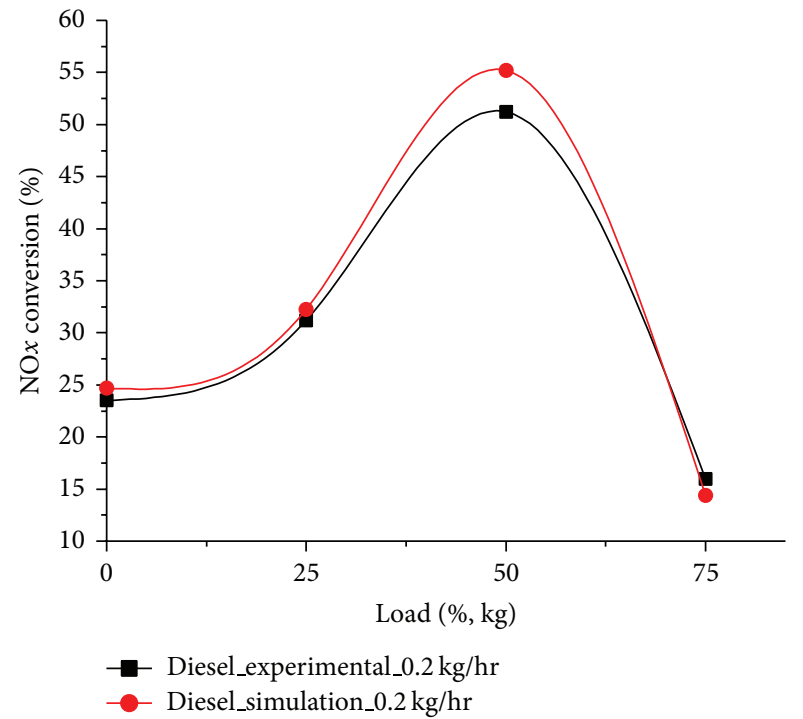

(a)

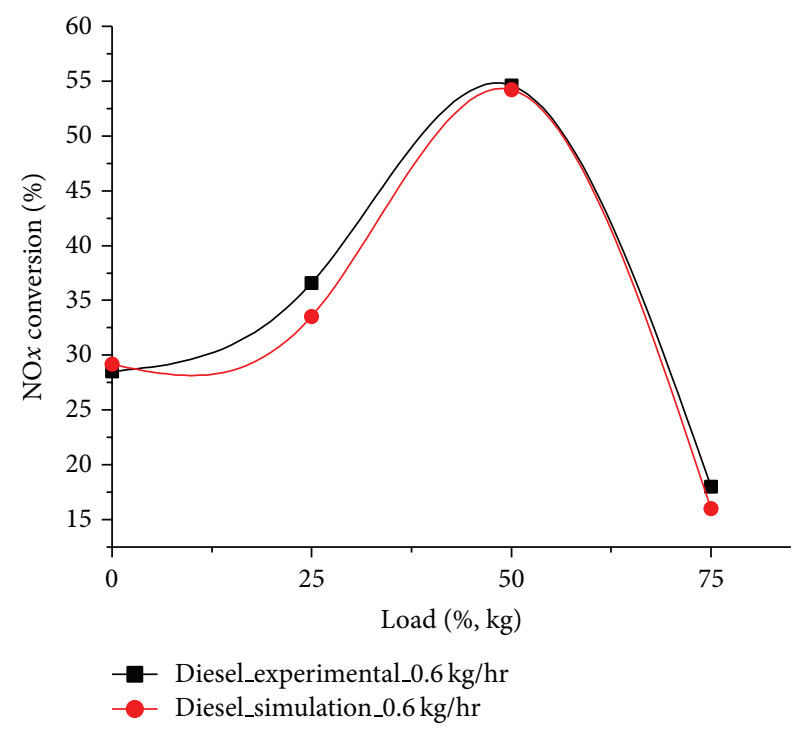

(c)

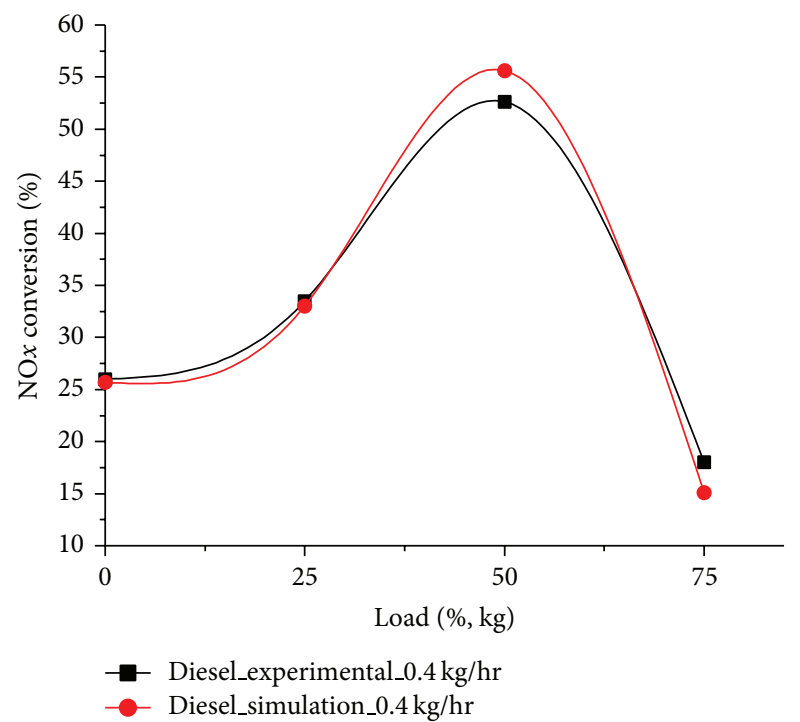

(b)

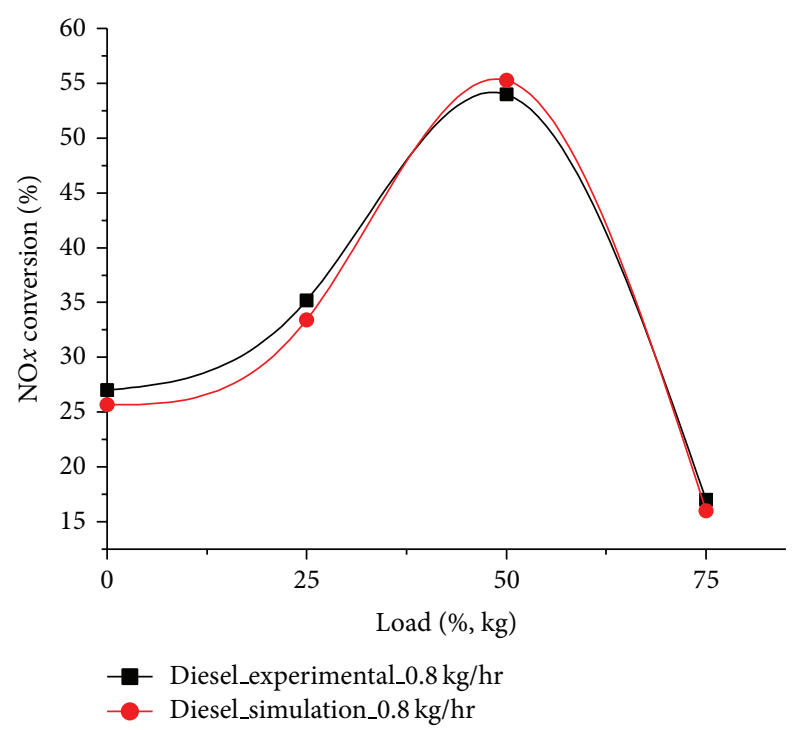

(d)

FIGURE 5: NO $x$ conversion versus percentage of load. 
are obtained. The conversion is more here due to higher exhaust gas temperature and higher reaction rate.

But at $75 \%$ load, the NOx conversion is reduced drastically due to increased exhaust gas temperature. At very high temperature $\left(>450^{\circ} \mathrm{C}\right)$ the catalyst selectivity goes on decreasing due to sintering effect of the catalyst [6] and desorption of ammonia [7] through the walls of monolith. Another reason for the lower NOx conversion at $75 \%$ load is the increased emission of hydrocarbons as explained in the Introduction part. Figure 6 explains the concentration of unburnt hydrocarbons for different load conditions.

At $75 \%$ load $34 \mathrm{ppm}$ of $\mathrm{HC}$ can be liberated, when compared with no load where just $13 \mathrm{ppm}$ of $\mathrm{HC}$ emission is found. When there is more emission of $\mathrm{HC}$ at higher temperature, the carbon particles deposit at the pores of the catalyst, which results in lower $\mathrm{NO} x$ conversion.

The $\mathrm{NH}_{3}$ conversion is another parameter, which will greatly influence NOx conversion. The concentration of ammonia can be calculated in different ammonia flow rate. Four samples of 1NHCL acid had been taken in beakers. Ammonia gas was passed through these samples for different ammonia flow rates varying from $0.2 \mathrm{~kg} / \mathrm{hr}$ to $0.8 \mathrm{~kg} / \mathrm{hr}$. The titration was carried out against $1 \mathrm{~N} \mathrm{NaOH}$. Also a blank titration was carried out for $1 \mathrm{~N} \mathrm{HCL}$ acid without ammonia gas passing through it, against $1 \mathrm{~N} \mathrm{NaOH}$. The readings were tabulated and the concentration is calculated by subtracting both the readings. It has been found that, as the ammonia flow rate increases, the concentration of ammonia also increases. From Figure 7, it can be noted that, for $0.2 \mathrm{~kg} / \mathrm{hr}$ ammonia flow rate, $400 \mathrm{ppm}$ ammonia concentration is obtained. Similarly for $0.4 \mathrm{~kg} / \mathrm{hr}, 0.6 \mathrm{~kg} / \mathrm{hr}$, and $0.8 \mathrm{~kg} / \mathrm{hr}$ ammonia flow rate, $450 \mathrm{ppm}, 550 \mathrm{ppm}$, and $600 \mathrm{ppm}$ ammonia concentrations are obtained.

Ammonia slip is the major disadvantage in SCR system, which will harm the environment and cause health problems. Hence, $\mathrm{NH}_{3}$ conversion is the major focus of study in the current work. Figure 8 explains the $\mathrm{NH}_{3}$ conversion with respect to varying load conditions.

From Figure 5, it was found that there is no much difference in $\mathrm{NO} x$ conversion by varying ammonia flow rate from $0.2 \mathrm{~kg} / \mathrm{hr}$ to $0.8 \mathrm{~kg} / \mathrm{hr}$. Hence, the study is focused on to find out the optimum ammonia inlet concentration which will result in the maximum $\mathrm{NH}_{3}$ conversion. From Figure 8, it has been found that, using $0.2 \mathrm{~kg} / \mathrm{hr}$ ammonia flow rate, the maximum conversion of $24 \%$ of $\mathrm{NH}_{3}$ conversion was achieved. Since the ammonia flow meter used in the experiment can measure a minimum of $0.2 \mathrm{~kg} / \mathrm{hr}$ ammonia flow rate where ammonia concentration was found to be $400 \mathrm{ppm}$, the simulation work has been extended by again minimizing the ammonia inlet concentration, to find out the maximum $\mathrm{NH}_{3}$ conversion efficiency.

The ammonia inlet concentration was varied from $100 \mathrm{ppm}$ to $400 \mathrm{ppm}$ to find out the maximum $\mathrm{NH}_{3}$ conversion. It has been observed that, below $100 \mathrm{ppm}$ ammonia inlet concentration, the $\mathrm{NO} x$ conversion as well as $\mathrm{NH}_{3}$ conversion is drastically reduced. Hence, ammonia inlet concentration was limited to $100 \mathrm{ppm}$. Figure 9 explains the

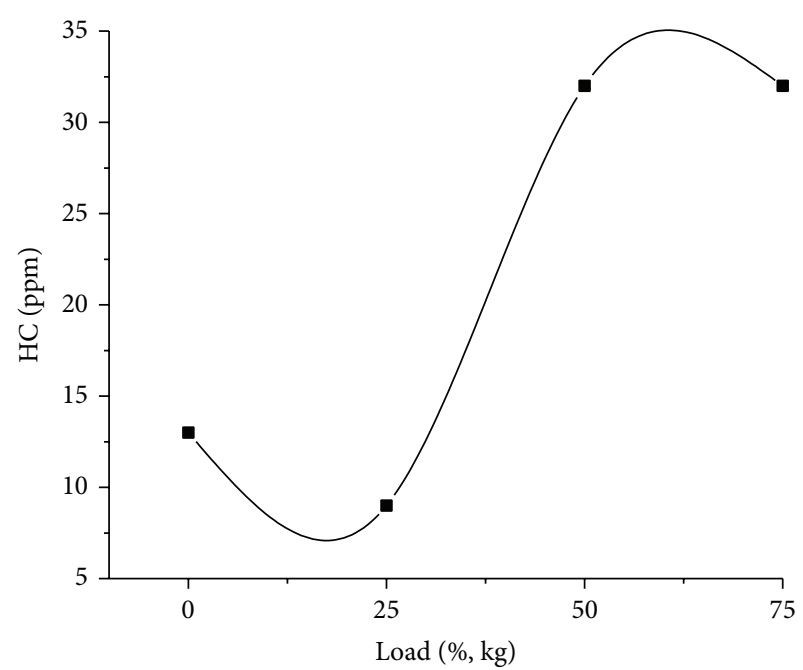

FIgURE 6: Hydrocarbon emission versus percentage of load.

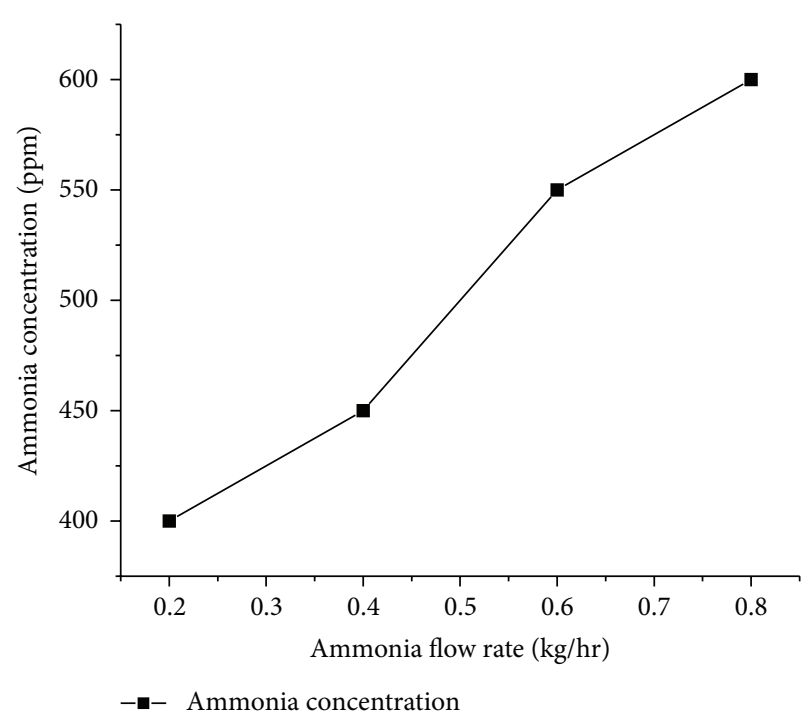

FIGURE 7: Variation of $\mathrm{NH}_{3}$ concentration with respect to inlet ammonia flow rate.

$\mathrm{NH}_{3}$ conversion rate with respect to varying ammonia inlet concentration.

It was found that as the ammonia inlet concentration reduces, the $\mathrm{NH}_{3}$ conversion rate increases. At $50 \%$ of full load and $100 \mathrm{ppm}$ ammonia inlet concentration, $98 \%$ of $\mathrm{NH}_{3}$ conversion was achieved. Similarly for $100 \mathrm{ppm}$ ammonia inlet concentration, at no load condition, at $25 \%$ of full load, and at $75 \%$ of full load $13 \%, 36 \%$, and $41 \%$ of $\mathrm{NH}_{3}$ conversion were achieved. This reveals that $100 \mathrm{ppm}$ ammonia inlet concentration is the optimum concentration, which will result in the maximum $\mathrm{NH}_{3}$ conversion. The corresponding NO $x$ conversion is also given in Figure 10. It has been found that there is slight increment at $50 \%$ of load, where $58 \%$ of NO $x$ conversion was achieved. Hence, it can be concluded that the Cordierite/Pt catalyst will give a maximum of $58 \%$ of NO $x$ conversion at $100 \mathrm{ppm}$ of ammonia inlet concentration. 


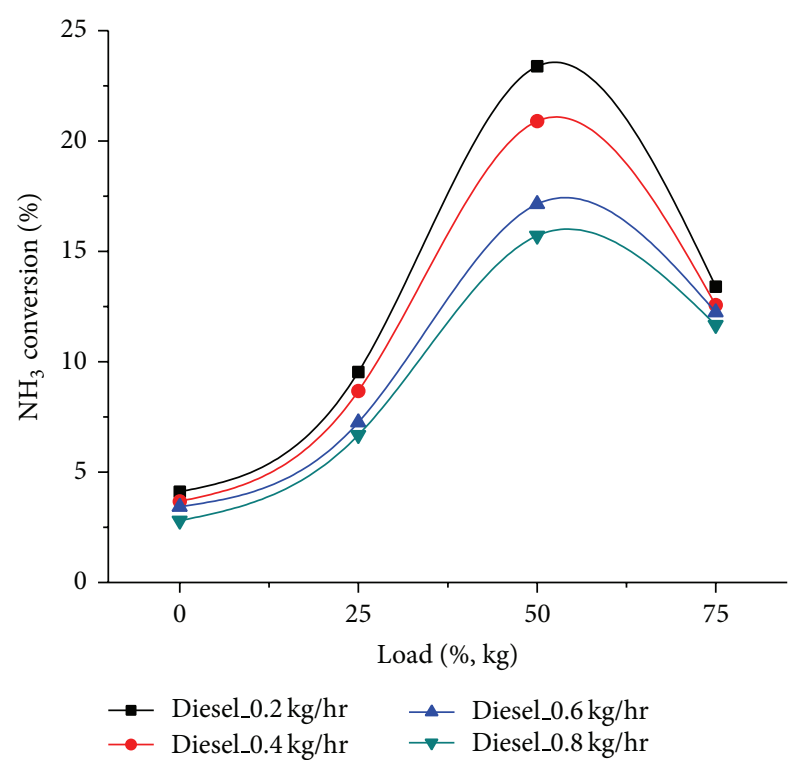

FIGURE 8: $\mathrm{NH}_{3}$ conversion versus percentage of load.

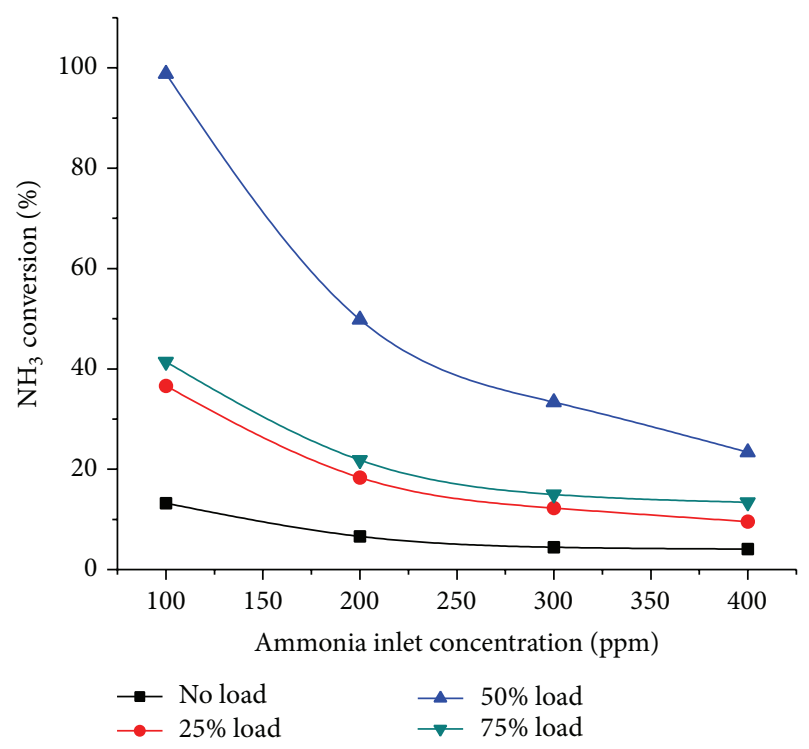

FIGURE 9: $\mathrm{NH}_{3}$ conversion versus ammonia inlet concentration.

\section{Conclusions}

(1) It has been found that, up to $0.6 \mathrm{~kg} / \mathrm{hr}$ ammonia induction, the $\mathrm{NO} x$ conversion goes on increasing, whereas, at $0.8 \mathrm{~kg} / \mathrm{hr}, \mathrm{NO} x$ conversion is slightly reduced due to desorption of ammonia and blockage of pores in a catalyst.

(2) At 50\% load and for all the ammonia flow rate conditions, $>50 \%$ of $\mathrm{NO} x$ conversion has been achieved due to higher exhaust gas temperature, where catalyst shows better selectivity, which results in conversion of $\mathrm{NO} x$ into free nitrogen $\left(\mathrm{N}_{2}\right)$.

(3) At $75 \%$ load and for all ammonia flow rate conditions, the NOx conversion has been reduced drastically,

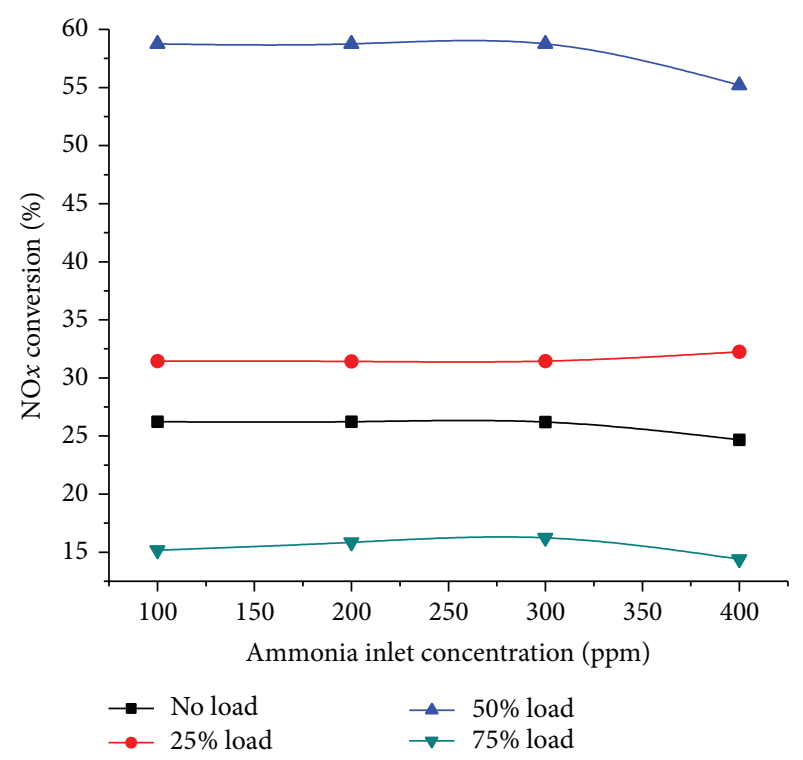

FIGURE 10: NO $x$ conversion versus ammonia inlet concentration.

because of ammonia desorption and increased emission of unburnt hydrocarbons.

(4) It was found that as the ammonia inlet concentration reduces, the $\mathrm{NH}_{3}$ conversion goes on increasing, where a slight increment in $\mathrm{NO} x$ conversion is only observed. It concludes that Cordierite/Pt catalyst will give a maximum of $58 \%$ of $\mathrm{NO} x$ conversion at $100 \mathrm{ppm}$ of ammonia inlet concentration.

\section{Conflict of Interests}

The authors declare that there is no conflict of interests regarding the publication of this paper.

\section{Acknowledgments}

The authors greatly acknowledge AVL-AST for providing software AVL FIRE for conducting the simulation work.

\section{References}

[1] A. J. Sullivan and A. J. Doherty, " $\mathrm{NH}_{3}$ and Urea in the selective catalytic reduction of $\mathrm{NO} x$ over oxide-supported copper catalysts," Applied Catalysis B: Environmental, vol. 55, no. 3, pp. 185194, 2005.

[2] L. Lietti, I. Nova, E. Tronconi, and P. Forzatti, "Transient kinetic study of the SCR-DeNO $x$ reaction," Catalysis Today, vol. 45, no. 1-4, pp. 85-92, 1998.

[3] J. Gieshoff, A. Schäfer-Sindlinger, P. C. Spurk, and J. A. A. van den Tillaart, "Improved SCR systems for heavy duty applications," SAE Technical Paper 2000-01-0189, 2000.

[4] I. Malpartida, O. Marie, P. Bazin, M. Daturi, and X. Jeandel, "An operando IR study of the unburnt $\mathrm{HC}$ effect on the activity of a commercial automotive catalyst for $\mathrm{NH}_{3}$-SCR," Applied Catalysis B: Environmental, vol. 102, no. 1-2, pp. 190-200, 2011. 
[5] I. Heo, Y. Lee, I.-S. Nam, J. W. Choung, J.-H. Lee, and H.-J. Kim, "Effect of hydrocarbon slip on NO removal activity of CuZSM5, FeZSM5 and $\mathrm{V}_{2} \mathrm{O}_{5} / \mathrm{TiO}_{2}$ catalysts by $\mathrm{NH}_{3}$," Microporous and Mesoporous Materials, vol. 141, no. 1-3, pp. 8-15, 2011.

[6] S. Pritchard, "Optimizing SCR catalyst design and performance for coal-fired boilers," in Proceedings of the EPA/EPRI Symposium on Stationary Combination NOx Control, 1995.

[7] I. Nova, L. Lietti, E. Tronconi, and P. Forzatti, "Dynamics of SCR reaction over a $\mathrm{TiO}_{3}$-supported vanadia-tungsta commercial catalyst," Catalysis Today, vol. 60, no. 1, pp. 73-82, 2000. 

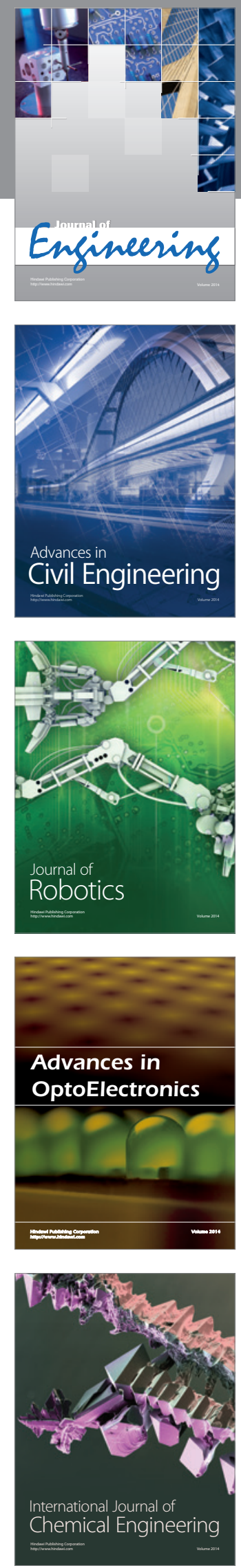

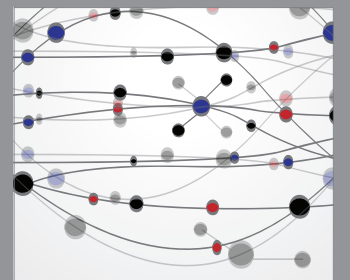

The Scientific World Journal
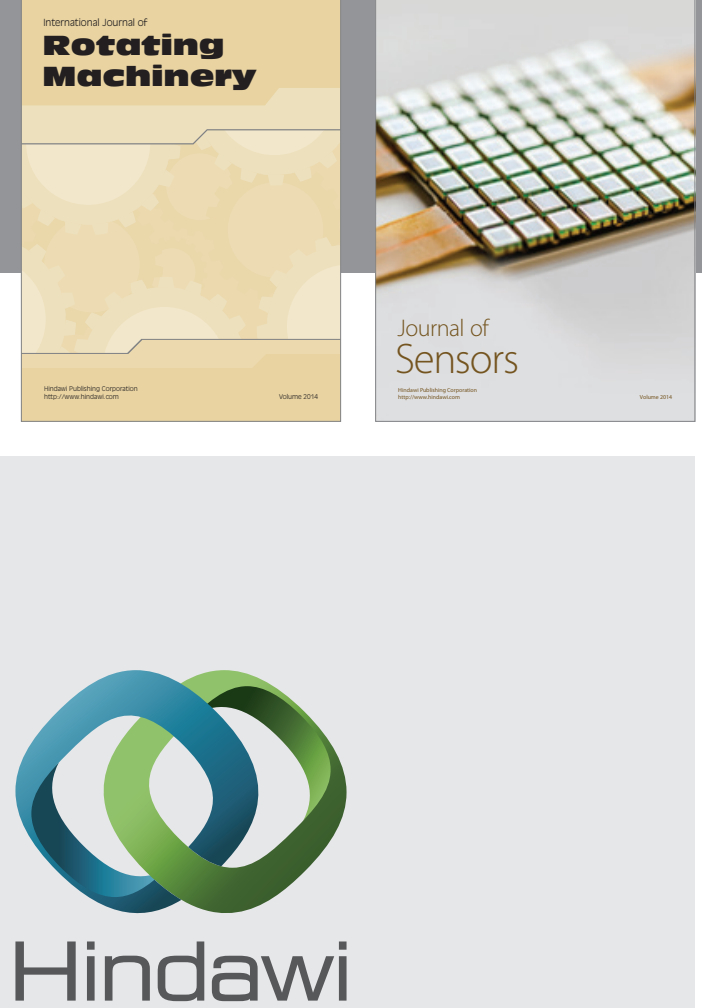

Submit your manuscripts at http://www.hindawi.com
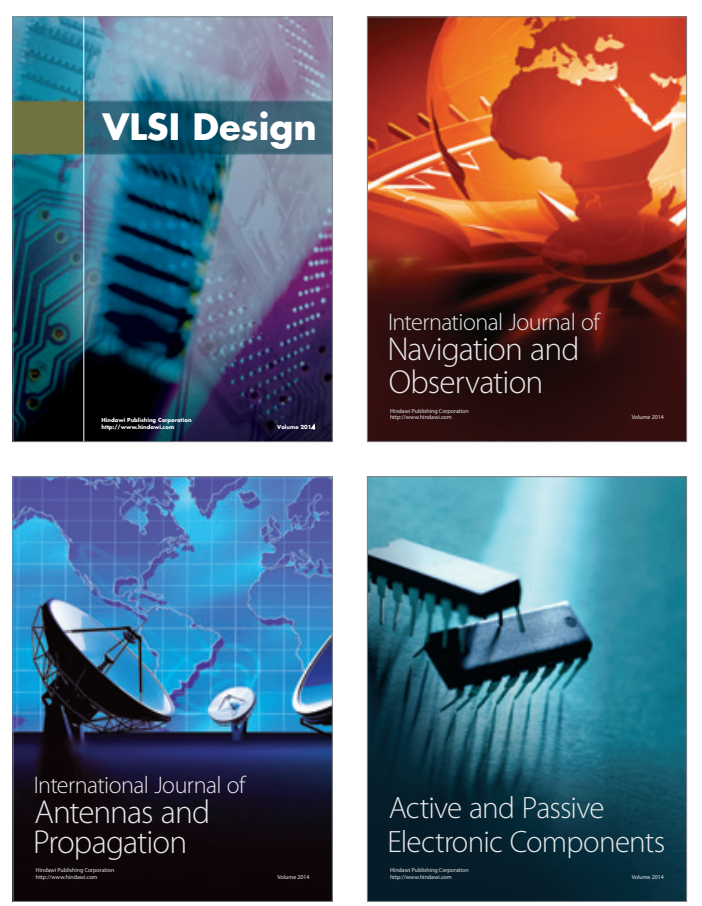
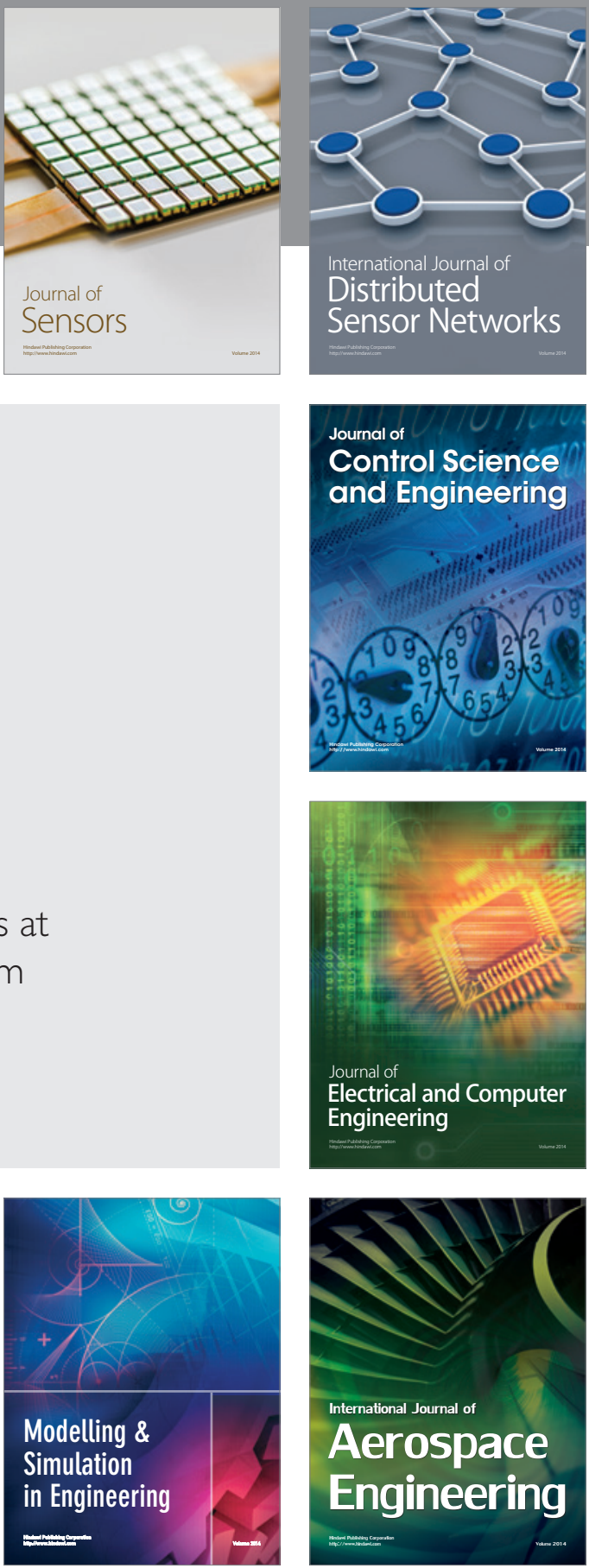

Journal of

Control Science

and Engineering
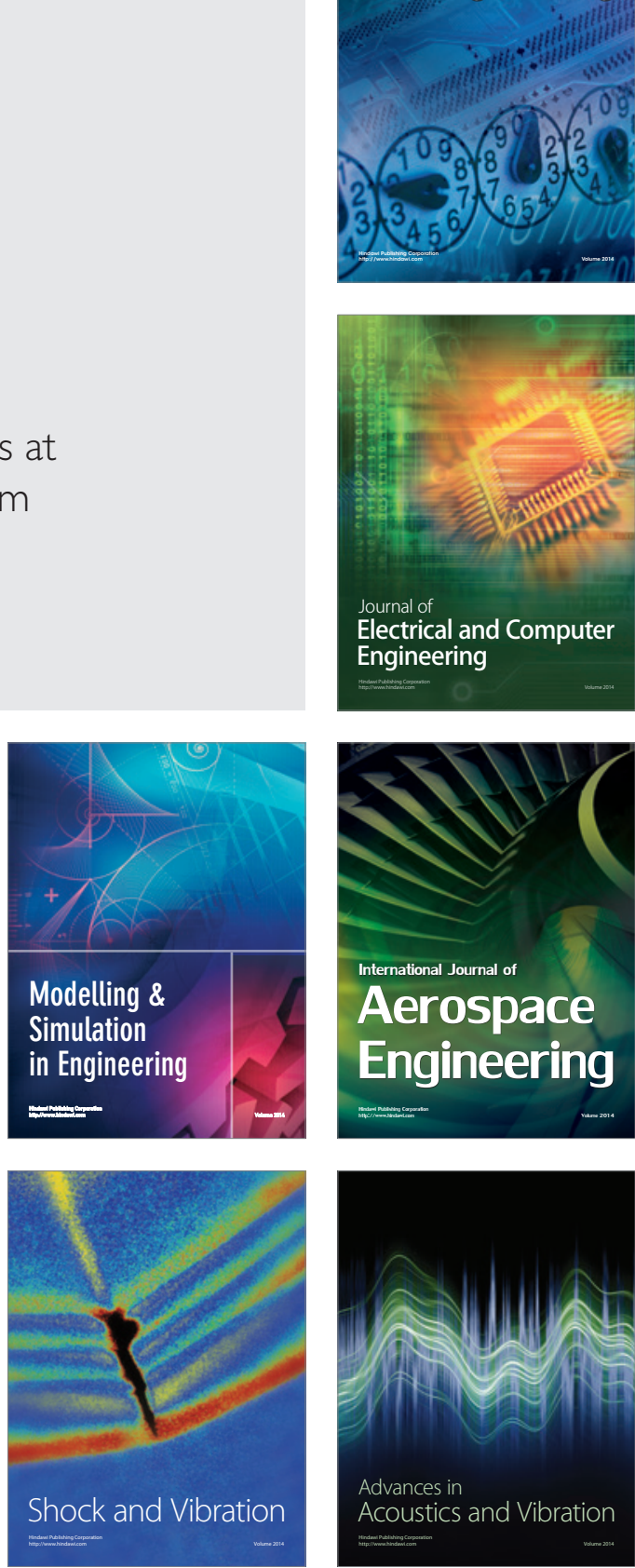